\section{The Correlation Between Burnout and Psychological Well-Being in Coffee Shop Baristas Affected by the Covid-19 Pandemic}

\author{
Anita Hariyanti*, and Nur Eva
}

Faculty of Psychology Education, State University of Malang

Abstract. This study aimed to determine the correlation between burnout and psychological well-being in coffee shops baristas affected by the Covid-19 pandemic. A descriptive quantitative and correlational approach was used. The participants included 70 coffee shop baristas located in Jalan Sudimoro, Lowokwaru Sub-District, Malang City, recruited with quota sampling. The research instruments consisted of a psychological well-being scale adapted from Eva \& Bisri [1] and a burnout scale adapted from Maslach \& Jackson [2]. The results showed that there was a significant negative relationship $(r=-0.272 ; p=0.023<0.05$ ). This indicated that the lower the burnout experienced by the baristas, the higher their psychological well-being.

Corresponding Author: Anita Hariyanti; email:

anitahariyanti06@gmail.com

Dates

Published 28 January 2022

Publishing services provided by Knowledge E

(c) Anita Hariyanti, and Nur Eva. This article is distributed under the terms of the Keywords: burnout, psychological well-being, barista, Covid-19

\section{Introduction}

The development of coffee-related business such as coffee corners or commonly referred to as coffee shops in Indonesia is experiencing rapid development. Based on the results of the research conducted by TOFFIN and MIX MarComm Magazine, the number of coffee shops in Indonesia in August 2019 had reached more than 2,950 outlets [3]. The owners of these coffee shops usually develop their businesses in strategic areas close to campuses and offices. Campuses are strategic choices because the coffee shops' marketing targets are university and school students who want to spend their leisure time or do their assignments there. Offices are also strategic places because many of their employees want to be more practical in enjoying coffee. The taste of the coffee served depends on the craft of the coffee makers or so-called baristas. The definition of barista etymologically comes from Italian which means bartender, which is one who serves all kinds of drinks, not only coffee [4].

The rapid development of coffee shops in Indonesia has also resulted in tough competition between coffee shops. There is an increase in demand and the rapid 
to maintain their business in the middle of such tough competition. The obstacle experienced by coffee businessmen lately is Covid-19 pandemic. This pandemic occurred at the end of 2019 which began with the spread of a virus originating from Wuhan City, the Capital of Hubei Province, Central China. WHO gave the virus a name. It is called as severe acute respiratory syndrome coronavirus 2 (SARS-CoV-2) which is the cause of Covid-19. This virus causes many serious impact on people in Indonesia, starting from the health impact, the economic impact, and also the psychological impact on the community.

The economic impact is marked by the competition between coffee shops so that it has further impact on the psychology of the coffee shops' owners. The psychological impact that occurs is a decrease in the psychological well-being of individuals. Psychological well-being is a positive attitude that exists in individuals towards themselves and others [5]. Those individuals can make their own decisions so that they can regulate their own behavior, create and regulate an environment that is compatible with their needs, and they can set their own goals, i.e. making their life meaningful, and the existence of their efforts to explore and develop themselves. Spector explained that employees who have high psychological well-being will tend to be cooperative, easier to help their colleagues, punctual in everything, efficient, and last longer in an organization [6]. Employees who have low psychological well-being will not be able to realize their strengths and weaknesses, besides that they will have difficulty in developing positive relationships with whoever living around them, unable to determine their life goals and cannot create a supportive environment for them [7].

In the coffee-related business world, this pandemic affects their every-day sales. Many coffee shops have experienced a decline in turnover due to this pandemic. The decrease in the number of buyers and the implementation of PSBB (Large-Scale Social Restrictions) also affected the decline in coffee shop turnover, resulting in a reduction in the number of employees. This reduction in the number of employees will have an impact on an increased workload, which can lead to employees' burnout. Burnout can also affect the mental health of an individual, especially on the individual's psychological well-being. The existence of the aspects of psychological well-being in individuals will play a role in the formation of burnout. Aspects of psychological wellbeing consisted of self-acceptance, positive relationships with others, independence, environmental mastery, life goals, and self-development [7].

The increased workload makes the baristas experience psychological disorders in the form of stress. Prolonged stress will result in a condition called burnout. Burnout is a form of stress that arises due to excessive work so that it has an impact on a lack of energy and interest in work [8]. Not only workload, burnout also occurs because wages or income 
are not commensurate with what one does. Working hours that are too excessive can also cause work stress and physical fatigue. There are three dimensions that cause burnout, namely emotional exhaustion, depersonalization, and low self-achievement [9]. Baristas who experience burnout will be disturbed in performing the work they are doing.

This research was conducted on the baristas at coffee shops who are affected by the pandemic. After conducting interviews with several baristas who work in different coffee shops, it was found out that on average they experienced prolonged work stress. One of the informants felt emotional exhaustion, i.e. he still feels tired even though he has enough rest, and the lack of enthusiasm is felt so he withdraws from his work environment. Other sources also feel that there was an excessive workload. The existence of long working hours that are not proportional to the income earned is also a factor in the emergence of psychological disorders in the form of stress. In the factor of low psychological well-being, it is found out that there is also a lack of self-acceptance. This can be seen when the informant tells that he is dissatisfied with himself. He often experiences disappointment with what he receives, which is not commensurate with what he strives for or contributes to his work. The supporting factors for low psychological well-being are the lack of purpose in life and lack of mastery of the environment, which is marked by difficulties in managing daily tasks so that the individual does not have goals or targets and also feels unable to change things in his/her surroundings so they can feel more comfortable.

The results of research regarding the correlation between burnout and psychological well-being in psychiatric nurses in India, showed that a person who has good psychological well-being and no psychiatric history will avoid burnout [10]. In addition, research regarding the correlation between psychological well-being and burnout of the nurses at Dr. Radjiman Wediodiningrat Lawang Mental Hospital, showed that the higher a person's psychological well-being, the lower the burnout experience, and vice versa [11]. This study explained that internal factors can influence the formation of an individual's psychological well-being on the occurrence of burnout. The research regarding the correlation between psychological well-being and burnout of the employees of a cigarette factory in Malang showed that employees who have low psychological wellbeing will experience high level of burnout [12]. This is indicated by the existence of low results on aspects of psychological well-being, namely environmental mastery and personal growth so that they affect the emergence of burnout.

The importance of the researches on burnout can help a company in developing its employees' productivity and the company's performance will be even better. Supporting aspects in improving psychological well-being can also be influential in 
helping to develop the company. The importance of increasing psychological wellbeing in individuals can also make the work environment better. The objectives of this study are: (i) to describe the level of burnout of the coffee shops' baristas affected by Covid-19 pandemic; (ii) to describe the level of psychological well-being of the coffee shops' baristas affected by Covid-19 pandemic, (iii) to determine the correlation between burnout and psychological well-being in the coffee shops' baristas affected by Covid-19 pandemic.

\section{Literature Review}

Psychological well-being is a positive attitude that exists in individuals towards themselves and others, where they can make their own decisions so that they can regulate their own behavior, create and regulate an environment that is compatible with their needs, and develop the existence of their life goals that make their lives more meaningful, and the existence of an effort to explore and develop themselves. Psychological well-being is a balance between psychological, social, and physical resources dealing with the challenges in life that require these resources [13]. Psychological well being has 6 aspects, namely self-acceptance, positive relationships with others, independence, ability to control the external environment, life goals, and development one's potential [7]. There are several factors that support the formation of psychological well-being, namely social support, socio-economic status, social networks, religiosity, personality, and stress.

Burnout is a state of physical, mental, and emotional exhaustion that occurs due to the pressure one experienced, high emotional involvement and coupled with the high standard of success of an individual [14]. Burnout is a result of a decrease in individual strength, causing fatigue that is experienced when dealing with problems [15]. Maslach and Jackson defined burnout as a syndrome of emotional exhaustion and cynicism that often occurs between individuals who do work [16]. Burnout has 3 dimensions of burnout, namely emotional exhaustion, depersonalization, and decreased selfachievement [9]. Whereas the factors that influence the formation of burnout are environmental factors and individual factors. Environmental factors consist of excessive workload and monotonous work, control, inappropriate rewards or token, conflict, loss of justice, and values. While individual factors consist of demographic factor and personality factor [9]. 


\section{Method}

This research applied descriptive quantitative approach and correlational research method. Correlational research aimed to determine the correlation between the variables under study. The research instrument used was a burnout scale adapted from Maslach \& Jackson [2] and a psychological well-being scale adapted from Eva \& Bisri [1]. The validity of the burnout scale obtained as many as 22 valid items which means all items can be used. On the psychological well-being scale, 15 valid items were obtained and there were 3 invalid items, but in this study all scales were still used because the psychological well-being scale was standardized. Both scales have a reliability value of 0.861 which means high on the burnout scale and 0.673 which means quite high on the psychological well-being scale, so it can be concluded that both scales can be used in this research.

The population of this study was coffee shops' baristas affected by Covid-19 pandemic located on Jalan Sudimoro, Lowokwaru Sub-District, Malang City. The samples in this study were 70 people with the criteria of working as coffee shops' baristas who worked on Jalan Sudimoro, Lowokwaru Sub-District, Malang Regency and aged from 19 to 25 years. The sampling technique used in this research was quota sampling. Quota sampling is a technique for determining samples from a population that have certain characteristics that are matched to the desired number [17].

\subsection{Data Analysis}

\subsubsection{Assumption Test}

In this study, the assumption test was used to determine whether the research data could be tested with parametric data or not. The assumption test used is the normality test with a significance rule exceeding 0.05 (sig. $>0.05$ ) so that it can be said to be normally distributed. The normality test in this study used the Kolmogorov-Smirnov technique. Furthermore, linearity test was also conducted to see the existence of a regression line between the two variables with a significance value of (sig. $>0.05$ ) so that it is considered linear.

\subsubsection{Hypothesis Testing}

In this study, in order to perceive the correlation between two research variables, a hypothesis testing was carried out by using a correlation test. Correlation test was conducted by using product-moment Pearson correlation. The criteria for those two 
TABLE 1: Coffee Shop Baristas Characteristics Data.

\begin{tabular}{|c|c|c|c|}
\hline \multicolumn{2}{|c|}{ Characteristic Type } & \multirow{2}{*}{$\begin{array}{l}\text { Frequency } \\
5\end{array}$} & \multirow{2}{*}{$\begin{array}{l}\text { Percentage (\%) } \\
7.1\end{array}$} \\
\hline Age & 19 & & \\
\hline & 20 & 8 & 11.4 \\
\hline & 21 & 14 & 20 \\
\hline & 22 & 21 & 30 \\
\hline & 23 & 10 & 14.3 \\
\hline & 24 & 4 & 5.7 \\
\hline & 25 & 8 & 11.4 \\
\hline & Total & 70 & 100 \\
\hline \multirow[t]{3}{*}{ Sex } & Male & 38 & 54.3 \\
\hline & Female & 32 & 45.7 \\
\hline & Total & 70 & 100 \\
\hline
\end{tabular}

TABLE 2: Burnout score categorization.

\begin{tabular}{l|l|l|l} 
Classification & Norm & Number & Percentage (\%) \\
\hline Low & $X<66$ & 40 & 57.1 \\
Moderate & $66<X \leq 110$ & 30 & 42.9 \\
High & $66 \leq X$ & 0 & 0
\end{tabular}

variables that can be said to be significantly correlated is if the significance number is less than 0.05 (sig $\leq 0.05$ ).

\section{Result and Discussion}

\subsection{Result}

\subsubsection{Descriptive Analysis}

(i) Coffee Shop Baristas Characteristics Data

Based on the results of table 1 above, it can be concluded that most of the coffee shop baristas are 22-year-old. Furthermore, most of the coffee shop baristas are male.

(ii) Burnout

Based on the results of categorization, the data obtained that 40 respondents with a percentage of $57.1 \%$ have low burnout level and 30 respondents with a percentage of 42.9\% have moderate burnout level.

(iii) Psychological Well-Being

Based on the results of the categorization, it is obtained data that 15 respondents with a percentage of $21.4 \%$ have a high psychological well-being level, 54 respondents with 
TABLE 3: Categorization of Psychological Well-Being Scores.

\begin{tabular}{l|l|l|l} 
Classification & Norm & Number & Percentage (\%) \\
\hline Low & $X<54$ & 1 & 1.4 \\
Moderate & $54 \leq X<90$ & 54 & 77.1 \\
High & $90 \leq X$ & 15 & 21.4
\end{tabular}

TABLE 4: Normality Test Results.

\begin{tabular}{l|l|l|l} 
Variable & Significance & Significance Level & Remarks \\
\hline Burnout & 0.200 & 0.05 & Normal \\
\hline Psychological Well-Being & 0.200 & 0.05 & Normal
\end{tabular}

a percentage of $77.1 \%$ have a moderate psychological well-being level, and 1 respondent with $1.4 \%$ has a low psychological well-being level.

\subsubsection{Assumption Test Results}

(i) Normality Test

Based on the results of the normality test in table 4 above, it can be seen that the significance value ( $p$ ) of burnout is $0.200>0.05$ which means that the burnout variable is normally distributed and the significance value (p) of psychological well-being is 0.200 $>0.05$ which means the variable of psychological well-being is normally distributed. So, it can be concluded that the data from burnout and psychological well-being are normally distributed.

(ii) Linearity Test

Based on table 5 above, it is concluded that the significance test result is $0.075>$ 0.05 , which means that burnout and psychological well-being have a linear correlation.

\subsubsection{Hypothesis Testing Results}

(i) Correlation Test

Based on table 6 above, it is concluded that the significance obtained is 0.023 0.05 , which means that there is a significant negative correlation between burnout and psychological well-being. The correlation coefficient results obtained -0.272 which means the correlation between the two variables is opposite or negative. So it can be

TABLE 5: Linearity Test Results.

Variable
Burnout - Psychological Well-Being


TABLE 6: Correlation Test Result.

\begin{tabular}{|c|c|c|c|c|}
\hline Variables & $\begin{array}{l}\text { Correlation } \\
\text { Coefficient }\end{array}$ & Significanc & GRemarks & Conclusion \\
\hline $\begin{array}{l}\text { Burnout and Psycho- } \\
\text { logical Well-Being }\end{array}$ & -0.272 & 0.023 & $\begin{array}{l}\text { Sig. } \leq \\
0.05\end{array}$ & $\begin{array}{l}\text { Significant Nega- } \\
\text { tive Correlation }\end{array}$ \\
\hline
\end{tabular}

concluded that the higher the burnout experienced by the coffee shop baristas, the lower the psychological well-being they have, and vice versa, the lower the burnout experienced by the coffee shop baristas, the higher the psychological well-being they have.

\subsection{Discussion}

\subsubsection{An Overview of Burnout on Coffee Shop Baristas Affected by Covid-19 Pandemic}

The results of the descriptive analysis that have been done previously is the information stating that the burnout experienced by coffee shop baristas is in the low category. It can be seen from 40 respondents with a percentage of $57.1 \%$ with a low score and 30 respondents with a percentage of $42.9 \%$ with a moderate score. So it can be concluded that the majority of coffee shop baristas experience burnout in a low category so that it does not affect the quality of the work they do.

From the results of the description above, the coffee shop baristas have a low majority score in the aspect of the formation of burnout. In the aspect of emotional exhaustion with a total of 36 respondents with a percentage of $51.4 \%$ in the medium category. In the aspect of personal achievement obtained as many as 58 respondents with a percentage of $82.9 \%$ in the low category. As for the de-personalization aspect, 55 respondents are obtained with a percentage of $78.6 \%$ in the low category.

The low burnout level experienced by the coffee shop baristas can occur due to several factors. Burnout has two factors, namely work environment factors and individual factors [9]. Environmental factors consist of excessive workload, monotonous work, control, inappropriate rewards, conflict, loss of justice, and values. The individual factors consist of demographic factor and personality factor. Based on the results of this study, these two factors have no effect on causing burnout in coffee shop baristas and are supported by research results on every aspect of low burnout level.

1. (a) i. Psychological Well-Being of Coffee Shop Baristas Affected by Covid-19 Pandemic 
Based on the results of the descriptive analysis that has been done previously, it is found that the psychological well-being of the coffee shop baristas is in the medium category. This can be seen from 1 respondent with a percentage of $1.4 \%$ in the low category, 54 respondents with a percentage of $77.1 \%$ in the medium category, and 15 respondents with a percentage of $21.4 \%$ in the high category. So it can be concluded that the majority of coffee shop baristas have moderate psychological well-being level.

From the results of the description above, the coffee shop baristas have a moderate majority score in every aspect that supports a high psychological well-being category, with the scores obtained in each aspect in the medium category. These aspects include aspect of self-acceptance with a total of 42 respondents with a percentage of $60 \%$ in the medium category, aspect of positive relationships with others with a number of 58 respondents with a percentage of $82.9 \%$ in the moderate category, aspect of independence with a total of 46 respondents with a percentage of $65.7 \%$ in medium category, aspect of environmental control with a total of 49 respondents with a percentage of $70 \%$ in the medium category, aspect of life goals with a total of 57 respondents with a percentage of $81.4 \%$ in the medium category, and aspect of personal development with a total of 37 respondents with a percentage of $52.9 \%$ in medium category.

Psychological well-being is an individual's feelings about the activities one does in his/her daily life and leads to the disclosure of personal feelings on the results of his/her life experiences [5]. Based on the description of each aspect above, it can be concluded that these results support the high psychological well-being level of every coffee shop barista affected by Covid-19 pandemic.

\subsubsection{The Correlation between Burnout and Psychological Well-Being on Coffee Shop Baristas Affected by Covid-19 Pandemic}

Based on the results of the correlation test on burnout and psychological well-being hypothesis, it was found that there was a significant negative correlation. This means that if the burnout level is high, the psychological well-being level is low and vice versa. The results obtained are also in line with the research on the correlation of internal factors with the incidence of burnout in nurses which stated that the higher a person's psychological well-being, the lower the burnout experienced, so there is a close correlation between the two variables [11]. This study explained that emotional maturity and psychological well-being contributed to the burnout experienced by nurses at the IPCU of Dr. Radjiman Wediodiningrat Lawang Mental Hospital. The results of this study were also in line with research on the effects of psychological well-being and burnout on 
Korean Opticians' Job stress which showed a negative correlation between burnout and psychological well-being of optical shops' employees in Korea [18]. The study showed that when the employees experienced high level of burnout, their psychological wellbeing become low so that it will affect their sense of self-fulfillment, decreased their job satisfaction, and lower the level of their interpersonal relationships.

This study showed that coffee shop baristas affected by Covid-19 pandemic had quite high psychological well-being and low burnout level. This was supported by the results obtained in each of the supporting aspects and factors for the formation of psychological well-being and burnout. In the aspect of self-acceptance on psychological well-being, the results were quite high, while in the aspect of personal achievement on burnout showed low results. These results showed that the coffee shop baristas affected by Covid-19 pandemic had a positive attitude towards themselves, the life they live, and accept various aspect of their life positively.

The results of this study are in line with the results of research on the correlation of psychological well-being with burnout in nurses at the mental hospital Prof.lldrem Pemprov Medan which shows that aspects of independence, life goals, and self-acceptance on nurses achieved high results, so that the results of both researches had a significant negative correlation and did not develop the formation of burnout in an individual [18]. According to Lianawati a person with good psychological well-being will accept his/her condition as it is, so that he/she is able to establish good relationships and will be able to trust others, be able to regulate him/herself so that he/she manipulates his/her environment in accordance with his/her values, and has a purpose in his/her life and is able to develop the positive aspects that exist in him/her [11].

\section{Closing}

\subsection{Conclusion}

Based on the results of this study, it can be concluded that the coffee shop baristas affected by Covid-19 pandemic did not experience burnout so they had good psychological well-being. This statement was supported by the low results on every aspect that supports burnout. As for the factors that form burnout, namely environmental factors and internal factors also do not support the occurrence of burnout. Furthermore, the aspects which support psychological well-being also achieve high scores. So it can be concluded that coffee shop baristas who are affected by Covid-19 pandemic can accept their conditions as they are, so they can have good relationships with other people and 
have a purpose in life to develop their positive aspects and do not experience physical, mental, and emotional exhaustion because there are pressures at work.

\subsection{Suggestion}

Based on the research that has been done, there are several suggestions that can be given, namely as follows:

(i) For Coffee Shops' Baristas

It is hoped that coffee shop baristas who are affected by Covid-19 pandemic can improve their psychological well-being in order to prevent burnout from occurring. As for improving psychological well-being, such efforts can also prevent psychological impacts resulting from Covid-19 pandemic.

(ii) For the Next Researchers

It is hoped that the next researchers will develop their researches by expanding the scope of research respondents, i.e. not only conducted to the baristas but also to other respondents who have jobs with a high risk of burnout. Further researches can add more independent variables related to burnout and psychological well-being so those researchers will be able to observe more varied factors that can be correlated.

\section{Acknowledge, Funding \& Ethics Policies}

Thank you to the coffee shop baristas who were respondents in this study. The author received financial support from the Faculty of Psychology Education, State University of Malang for research, writing, and publication of this article.

\section{References}

[1] Eva N, Bisri M. Dukungan sosial, religiusitas, dan kesejahteraan psikologis mahasiswa cerdas istimewa. Prosiding Nasional Psikologi Klinis 2018 Perkembangan Masyarakat Indonesia Terkini Berdasarkan Pendekatan Biopsikososial. 6281796952018628179695srobona gdastidar628179695664515279Month and date of conference; city and country of conference.

[2] Maslach C, Jackson SE. The measurement of experienced burnout. Journal of Organizational Behavior. 1981;2(2):99-113. https://doi.org/10.1002/job.4030020205

[3] Sugianto D. Hasil riset: Kedai kopi di ri bertambah 2.000 dalam 3 tahun. Finance.Detik.com. 6281796942019628179694srobona 
gdastidar628179694664515283Month and date of publication. Available from: https://finance.detik.com/berita-ekonomi-bisnis/d-4826275/hasil-riset-kedai-kopi-diri-bertambah-2000-dalam-3-tahun

[4] Masdakaty Y. Sekilas tentang barista. Majalah Otten Coffee. 2015 Oct 31. Available from: https://majalah.ottencoffee.co.id/sekilas-tentang-barista/

[5] Ryff CD. Psychological well-being in adult life. Current Directions in Psychological Science. 1995;4(4):99-104. https://doi.org/10.1111/1467-8721.ep10772395

[6] Harter JK, Schmidt FL, Keyes CLM. Well-being in the workplace and its relationship to business outcomes: A review of the Gallup studies. Dalam flourishing: Positive psychology and the life well-lived. American 628179693Psychological628179693srobona gdastidar628179693664515279Location of publisher Association; 2003. https://doi.org/10.1037/10594-009

[7] Ryff CD, Keyes CLM. The structure of psychological well-being revisited. Journal of Personality and Social Psychology. 1995;69(4):719-727. https://doi.org/10.1037/00223514.69.4.719

[8] Schultz D, Schultz SE. Psychology and work today. 628179692Pearson628179692srobona gdastidar628179692664515283Location of publisher Education. Inc.; 2010

[9] Maslach C, Schaufeli WB, Leiter MP. Job burnout. Annual Review of Psychology. 2001;52(1):397-422. https://doi.org/10.1146/annurev.psych.52.1.397

[10] Chakraborty R, Chatterjee A, Chaudhury S. Internal predictors of burnout in psychiatric nurses: An Indian study. Industrial Psychiatry Journal. 2012;21(2):119-124. doi: 10.4103/0972-6748.119604

[11] Kholifah S, Soeharto S, Supriati L. Hubungan faktor-faktor internal dengan kejadian kelelahan mental (burnout) pada perawat. Jurnal Kesehatan Mesencephalon. 2016;2(4):251-259. DOI: http://dx.doi.org/10.36053/mesencephalon.v2i4.4

[12] Ardilla AS, Hakim GRU. Hubungan psychological well-being dengan burnout pada karyawan di salah satu pabrik rokok di Malang. Seminar Nasional Psikologi UM. 2020;1(1):128-135.

[13] Dodge R, Annette PD, Huyton J, Lalage DS. The challenge of defining wellbeing. International Journal of Wellbeing. 2012;2(3):222-235. DOI:10.5502/ijw.v2i3.4

[14] Leatz CA, Stoler MW. When works gets to be too much. World Executives Digest. 1993;14:11.

[15] Freudenberger HJ. The issues of staff burnout in therapeutic communities. Journal of Psychoactive Drugs. 1986;18(3):247-251. https://doi.org/10.1080/02791072.1986.10472354 
[16] Jeung DY, Kim C, Kun SJ. Emotional labor and burnout: A review of the literature. Yonsei Medical Journal. 2018;59(2):349-356. doi: 10.3349/ymj.2018.59.2.187

[17] 628179691Sugiyono628179691srobona gdastidar628179691664515284Initial of author. Statistika untuk penelitian. Bandung: Alfabeta; 2017.

[18] Ambarita TFA. Korelasi psychological wellbeing dengan burnout pada perawat Rumah Sakit Jiwa Prof.Ildrem Pemprovsu Medan. Jurnal Psikologi Universitas HKBP Nommensen. 2020;6(2):78-91. https://doi.org/10.36655/psikologi.v6i2.138 